\title{
A case of paediatric rectal prolapse without spontaneous reduction on arrival
}

\author{
Yoshihiro Aoki, Katsuhiko Kitazawa
}

Department of Pediatrics, Asahi General Hospital, Chiba, Japan

\section{Correspondence to}

Dr Yoshihiro Aoki, yaoki-hki@umin.ac.jp

Accepted 5 May 2017
To cite: Aoki Y, Kitazawa K. BMJ Case Rep Published Online First: [please include Day Month Year] doi:10.1136/bcr-2017220608

\section{DESCRIPTION}

Most cases of rectal prolapse in children are naturally reduced; thus, cases without spontaneous reduction are extremely uncommon. ${ }^{1}$ We report a girl (aged 2 years 8 months) with paediatric rectal prolapse without spontaneous reduction on arrival at the emergency department.

Although the patient had not been diagnosed with any specific disease, she had a history of hard stools and difficulty defecating. Four days before arriving at the hospital, she began toilet training to stop using diapers. She came to the hospital at night with her parents who described 'gut escaping from her anus'. On examination, she showed prolapse of the entire circumference of the rectum from the anus with mucosal bleeding (figure 1). Manipulative reduction was performed and she returned home, but the escape recurred several times. Considering her age and underlying constipation, we started outpatient management of constipation before referral to paediatric surgeon. At the time of surgical consultation, she no longer showed any recurrence.

When rectal prolapse is present without spontaneous reduction, it must be reduced immediately because this may lead to difficulty in manipulative

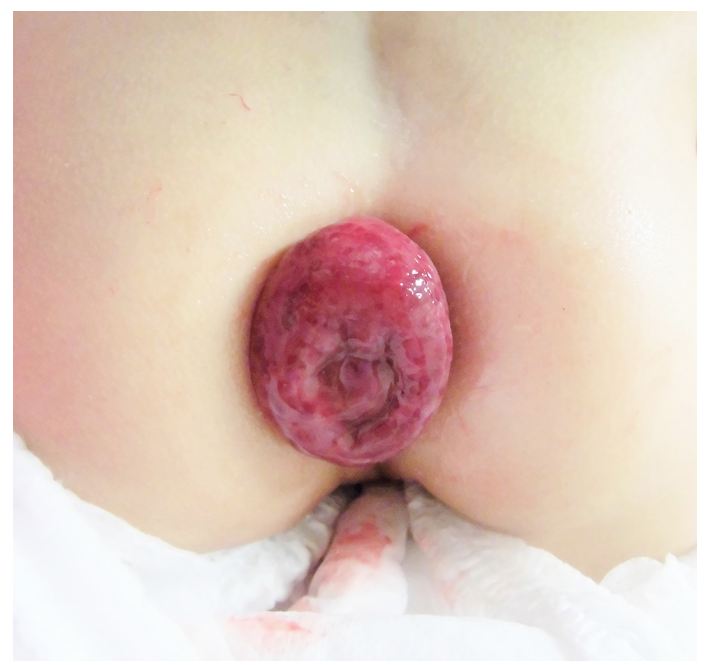

Figure 1 Examination of the anus. The patient showed prolapse of the entire circumference of the rectum from the anus with mucosal bleeding.

\section{Learning points}

- Rectal prolapse in children without spontaneous reduction is rare, but if presented, it must be reduced as soon as possible.

- When rectal prolapse is observed in children, paediatricians must consider the patient's chronic constipation history and provide appropriate bowel management.

- Surgeons should be consulted for cases with frequent recurrence even under conservative treatment to rule out underlying conditions, difficulty in manipulative reduction or children older than 4 years of age.

reduction due to congestion and oedema of mucosa. ${ }^{1}$ Although treatment is essentially conservative, cases with frequent recurrence or difficulty in manipulative reduction may require surgical intervention. ${ }^{2}$ Furthermore, it is said that children older than 4 years of age not responding to conservative treatment, without underlying conditions are the most important points to be aware of when consulting a paediatric surgeon. The most frequent cause of rectal prolapse in children is chronic constipation ${ }^{3}$; thus, bowel management is important in rectal prolapse. Infrequently, some cases may require a biopsy, colonoscopy or sigmoidoscopy to investigate other underlying conditions.

Contributors YA managed the patient, drafted the initial manuscript and approved the final manuscript as submitted. KK critically reviewed and revised the manuscript and approved the final manuscript as submitted.

Competing interests None declared.

Patient consent Obtained from guardian.

Provenance and peer review Not commissioned; externally peer reviewed.

(C) BMJ Publishing Group Ltd (unless otherwise stated in the text of the article) 2017. All rights reserved. No commercial use is permitted unless otherwise expressly granted.

\section{REFERENCES}

1 Cares K, El-Baba M. Rectal prolapse in Children: significance and management. Curr Gastroenterol Rep 2016;18:22.

2 Antao B, Bradley V, Roberts JP, et al. Management of rectal prolapse in children. Dis Colon Rectum 2005;48:1620-5.

3 Poelstra BA. et a/Rectal prolapse. In: Hoffman RJ, Wang VJ, Scarfone RJ, . eds. Fleisher and Ludwig's 5-minute pediatric emergency medicine consult. Philadelphia, PA: Wolters Kluwer Health/ Lippincott Williams \& Wilkins, 2011:808-9. 
Copyright 2017 BMJ Publishing Group. All rights reserved. For permission to reuse any of this content visit http://group.bmj.com/group/rights-licensing/permissions.

BMJ Case Report Fellows may re-use this article for personal use and teaching without any further permission.

Become a Fellow of BMJ Case Reports today and you can:

- Submit as many cases as you like

- Enjoy fast sympathetic peer review and rapid publication of accepted articles

Access all the published articles

- Re-use any of the published material for personal use and teaching without further permission

For information on Institutional Fellowships contact consortiasales@bmjgroup.com

Visit casereports.bmj.com for more articles like this and to become a Fellow 